\title{
From Sensibility to Sense-An Analysis on the Shift of Marianne's Views on Marriage in Sense and Sensibility
}

\author{
Yuchao Zhang \\ Shanxi Normal University, Linfen, China
}

\begin{abstract}
Jane Austen is an excellent female writer in the United Kingdom. Many of her works appeal to generation after generation of readers. She wrote and published six novels in total. Sense and Sensibility was one of her popular novels and first named as Elinor and Marianne. Elder sister Elinor is a rational girl who can control her temper appropriately. She loves Edward very much. However, the younger sister Marianne is very emotional. She pursues romantic love and fails to control her temper after the lovelorn. After experiencing many setbacks, Marianne understands many principles and corrects her childish viewpoints. Luckily, both of them get their true love finally.

By researching original book and other literatures as well as analyzing the shift of Marianne's behaviors and views on marriage from sensibility to sense, we can understand wise attitudes towards marriage. That is to say, when a woman chooses her Mr. Right, she should be more rational in love. This paper has great guiding importance for current women to seek their guidance in love. The paper will lead us to find what the rational views on marriage are and what we should do in marriage.
\end{abstract}

Index Terms - Jane Austen, Sense and Sensibility, Marianne, sensibility, views on marriage

\section{INTRODUCTION}

In early Britain, the vulgar Sentimentalism and Gothic novels were welcomed by many writers. They were filled with British literature and lasted for a long time. Since the novels refuted rationality and advocated personal feelings so they also called pre-romanticism. However, novels by Jane Austen inherited and developed the tradition of realism in English fiction writing. The novel Sense and Sensibility reflects writing background of the special era-patriarchal society. Women have to follow her husband both in family and society. The only judgment standard of women is her marriage. When she marries to a rich and handsome husband, she can have a wealthy and carefree life. The status of men decides the status of women. So women are always at a disadvantage in marriage since they have few options. Without money, they must learn to draw pictures, play musical instruments and other training to enrich and improve them for marrying a rich man to attain the higher social status.

The author Jane Austen likes to observe the society and people around her. She depicts love stories between men and women in peaceful country and her writing style is full of exquisite, concise as well as emotional. At the same time, she also exposes the dark side of woman's social status and criticizes this money-oriented marriage system. Her novel Sense and Sensibility truly reflects this main idea. Elinor and Marianne are responsible for appealing to woman's liberation. Although conditions of their family are common, both of the sisters have their own thoughts of love. Basing on two sisters, Jane Austen believes that although most women cannot struggle for embarrassing situation, they also have rights to pursue their happiness like pursuing freedom and equality. Although women are discrimination group, they must try their best to express their own real thoughts independently. Especially standing on Marianne's position, Jane Austen thinks women are easy to be impulsive and lost themselves in love and marriage so sensibility should be controlled by sense.

As a woman writer, Jane is concerned about woman's social status and tries her best to defend them. She criticizes the repression and inequality of patriarchal systems. It is favorable for women to free their mind and raise their status even today.

\section{LITERATURE REVIEW}

Sense and Sensibility was produced by a great and female writer whose name is Jane Austen. Her father was a knowledgeable priest and his wife was also a cultural connotation woman. Jane fell in love with reading books and her abilities to study independently were improved. Although she never goes to school and also does not read too many books, her interest in writing was cultivated by good family environment. She began to write some interesting stories when she was thirteen years old and she also showed wonderful ability of language expression. In 1800, Jane refused a suitor who was about to inherit assets from his guardian and never married. Four years later, her father passed away and Jane with her mother as well as her younger sister moved to another place. In 1816, Jane was ill, she was attacked by a 
serious disease so she had to receive treatment in Winchester in May 1817. But unfortunately, Jane passed away on July 18.

The life of Jane Austen was brief but extraordinary. Since she lived in a small grange, the people she communicated were all middle and small landowners or priests. Their cozy and easy living environment influenced Jane Austen so there were not social contradictions in her works. She was usually satirized human weakness like compliments, selfishness and overconfidence by depicting many comic scenes and her works were beneficial to change vulgar of novel writing. Few writers could approach Shakespeare in talent, but Jane Austen did it.

At the outset, Sense and Sensibility was named "Elinor and Marianne" by Jane Austen. That suggested the plot was mainly talk about Elinor, Marianne and their troublesome romance with their respective lovers. Elinor is the first daughter of Dashwood family. She is a kind and rational girl. Regardless what happens, she can always remain calm. Afterwards, she falls in love with Edward Ferrars, he is Aunt Fanny's brother. Even if they have to separate, Elinor can also control her emotion appropriately. When she hears Edward has already engaged with another girl Lucy, she is very shocked. But she persuades herself to accept this cruel fact. Although enormous grief and sadness strike Elinor, she does not want anyone to worry about her so she bears all misery. Even later, Edward is given up by his fiancee Lucy, Elinor does not change the beginner's mind. Edward is very moving and tells Elinor his true feeling. In this novel's final, they live happily together.

Elinor has a younger sister Marianne. With some personalities of smartness, enthusiasm, energy and sentiment, she always has romantic illusions in love. Her ideal lover should have handsome or attractive appearance and know how to be romantic. When Colonel Brandon showed appearance to her, Marianne does not want to accept him at all since he is too old to have opportunity to pursue other young ladies, even if he is scarcely thirty-five years old. Later, she comes across John Willoughby, a young man who is attractive and romantic. Marianne is appealed to this handsome youth and falls in love with him. She is crazy about him. However, Willoughby is a vain and promiscuous snob and abandons Marianne finally. Faced with this sudden blow, Marianne has no prepared. Dissolving into tears every day, she does not willing to control herself at all. She is too emotional to find herself in love and nearly loses her life in a heavy rain. Fortunately, she stands up again with Elinor's help and Colonel Brandon's care, and then she marries to this man who is old in her eyes and just knows little about romance. In Sense and Sensibility, Elinor represents sense and her younger sister Marianne represents sensibility. Although their roads to love not run smooth, they finally find their true love after experience many setbacks.

By comparing different emotional experience of two sisters, Jane Austen wants to tell readers that marriage is a serious and cautious problem. When a girl chooses her partner, inner beauty should be thought a lot of and beautiful appearance is secondary. Meanwhile, one cannot indulge himself in emotion and it should be restrained by sense.

Sense and Sensibility has been seen as one of Jane Austen's famous works since it was produced. Many scholars write relevant literatures about this book. As one of the researchers, Sun Yaling made a comment on Marianne and worried about her determined romanticism. She thought Marianne was like her mother with the same problem that was carelessness (Sun, 2012). She has very demands on her future husband and she likes to pursue the fantasy (Sun, 2012). By analyzing romantic characters of Marianne, Sun thought it is her dreamy nature that leads to self-loss, so we can understand the romantic views on marriage are what Marianne really wants before the lovelorn.

Sun also mentioned: Willoughby just wants to cheat Marianne's sincere heart by his handsome face and lordship. It destroys Marianne's illusion (Sun, 2012). In fact, Willoughby did love her. Although he also deceived another girl Mrs. Eliza and let her pregnant one year ago, he really loved Marianne in love period. The reason for Willoughby's leaving is lack of money so he decided to marry a rich girl Mrs. Gary. But precisely because of his betrayal Marianne has to be strong and walks out of the lovelorn shadow.

Another academic learner on Sense and sensibility is Lin Yin. She thought that Marianne paid more attention to emotion in the face of love, rather than money. When she makes a choice, Willoughby is obviously an ideal person even though he has only one thousand pounds each year. But Marianne should have at least two thousand pounds if she wants to have a wonderful life. However, she doesn't care because she loves Willoughby very much (Lin, 2013). As we all know, the happy marriage should base on material conditions, like earning, houses even cars. Although every girl wants to have romantic love, we must turn to real life eventually. The author Jane Austen supports this view of marriage. Most of her novels showed the realism in British. Even some features of her works are included in some characteristics of other fictions in twentieth century. So we can see some of Jane Austen's views are progressive. Therefore, many critiques about her works are produced. Zhang Li wrote the book which name is Character Analysis on Sense and Sensibility. He supported this view - the happy marriage should base on money. Nonetheless, girls should become brave and keep hopeful when they lost love, especially your spouse gives up you for lack of fortune.

Liang Xiangyang is a critic of Jane Austen's novels. He commented that the handsome or beautiful face would change but only the inner beauty would everlasting (Liang, 2010). Recently, a researcher Zhou Fang has written a paper about this novel. The sparkling point of this paper is that she revealed Jane Austen's views on love by using the perspective of appraisal theory. This comparison reminds us to think about the true love. Colonel Brandon is older but better than John Willoughby. At least, he always treats Marianne sincerely even though he knows she dislikes him. The data suggested that Jane Austen supported true love and opposed false love which base on good-looking appearance.

In his article on Analysis of Jane Austen's Views on Marriage, Qian Jin analyzed: “As a realistic writer, Jane Austen 
criticized someone pays more attention to money and gives too much importance to appearance and material conditions." (Qian, 2012, p. 268). He appreciated Jane Austen's foresight and thought it was significant for women today to self-inspect.

One of the topics in the research of Sense and Sensibility is the source of this novel's name. In this novel, sense and sensibility are expressed separately by two girls of Dashwood family, they are Elinor and Marianne, especially differences between their standpoints, actions and results. In her paper, a researcher Zhang Zhijuan thought that sense and sensibility should not be understood separately, Elinor represents sense but does not lose enthusiasm. Marianne represents sensibility but not always stupid and stubborn. She insisted that we should not ignore sensibility but keep a balance between reason and passion (Zhang, 2012).

Maybe most people only concerned about the shift of Marianne's views on marriage are from sensibility to sense, but only a few people focused on the balance between these two aspects. Zhang's standpoint is very creative and breaks through the traditional perspective. A new view about Sense and Sensibility was raised by Fu Jie in 2009. Actually speaking, Austen's perspective about marriage is also applied to modern marriage. It also reflects specific features: the contradiction and affinity (Fu, 2009). The contradiction and affinity are showed on characters in this novel: the traits of two sisters are contradictory. Elinor is calm and objective. Marianne is impulsive and subjective. But their characters become similar at the end of the novel so they tend towards the affinity, everyone wants to be like Elinor who balances sense with sensibility well in imagination. But in fact, most of them go deeper and deeper into love without putting rational factors into calculating. Views of Jane Austen are changed. Influenced by the traditional education, Jane prefers to keep rational awareness. But romanticism in the nineteenth century emphasized the individualism and idealism. Jane was more or less influenced by this trend of thought (Fu, 2009).

Another researcher Yang Huan focused on women's marriage patterns of Jane Austen's works. She analyzed that there were two types of patterns in her novels. First pattern was "call and response" and second pattern was "confession and introspection". In the pattern of "call and response", when Marianne was given up by her boyfriend Willoughby, Colonel Brandon comforted and cared her in time. That means "call". Marianne felt very moving and fell in love with Colonel Brandon at the age of nineteen. That means "response". If both sides could feel the call of love and respond actively, they would receive the steadfast love (Yang, 2013). In the pattern of "confession and introspection", integrated with western culture and dogmas, she thought pride and self-approbation were thought to belong to original sin. So people must find out the fault, express the confession and redeem the soul (Yang, 2013). Marianne must learn to selfreflection, correct her personality shortcomings and find her true love finally.

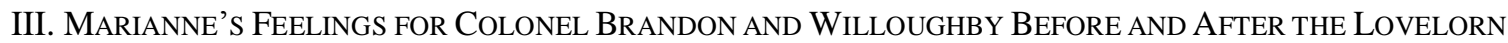

\section{A. Before the Lovelorn}

Marianne is the second daughter of Dashwood family. Her most obvious personality is sentimentality. In other words, she is easy to be sentimental and impulsive when meets something unknown, especially in the process of pursuing love. In contrast, her sister Elinor is a girl who has ability to control herself rationally. So Marianne was destined to experience more setbacks and learn to cope with them then she could grow up and made something well of herself.

Two men walk into Marianne's life. The first man she meets is Colonel Brandon who loves her deeply and carefully. The second is John Willoughby who she loves frantically. When facing with Brandon and Willoughby, choosing between sense and sensibility, what is Marianne's option? What is her feeling for the two men?

1. For Colonel Brandon

When Mrs. Dashwood talks about Colonel Brandon, Marianne always does not like him from her heart. Colonel Brandon is a gentleman who was thirty-five years old and married before. He hopes to find another kind girl as his spouse so he seems to like Marianne. On her childish views, she insists this gentleman is too old to have right to pursue his happiness. She even laughs at Brandon's disease, the rheumatism.

In chapter seven, there are some sentences about the appearance of Colonel Brandon. Compared with Willoughby, he is unattractive. Marianne sometimes looks down upon him as she prefers an active and young man. So she overlooks the sparkling points of Brandon. Later, she even talks about the weakness of Brandon with Willoughby. They consider that he is mediocre in all respect of life (Austen, 1994, p. 44).

Thus there are many romantic elements in Marianne's thought, she concerns on handsome appearance rather than inner beauty and she prefers the free and easy life. As a consequence, Marianne chooses Willoughby who is a handsome and romantic man.

2. For Willoughby

Willoughby is an ideal lover in Marianne's eyes. She loves him extremely crazy. When she saw him for the first eye, she was deeply attracted by this good-looking youth. As for Elinor and her mother, it is the first time when they see John Willoughby, as for Marianne, she is too shy to look at his face carefully like others. This young girl's heart is touched by this handsome and enthusiastic man so she takes part in all the admiration of the others.

Marianne and Willoughby are both like playing the piano, painting pictures and dancing. They also have same views on art and books. Soon, the two young people find they have many striking similarities. Especially Marianne, she insists that Willoughby must be her dream lover. Without a shadow of a doubt, Marianne, a pure and naive girl, lost her own direction in love. At this moment, sensibility conquers sense completely. Marianne does not want to hear a word about 
the weakness of Willoughby, not even Elinor.

There are many differences between Colonel Brandon and John Willoughby, one is mature and another is childish. Marianne is a romantic girl, she likes something new and fresh, hates the traditional doctrines. Obviously, Willoughby is an ideal husband she wants, so her attitudes towards Colonel Brandon and Willoughby are different.

\section{B. After the Lovelorn}

The turning point of the novel is Willoughby's leaving. He has to go to London right now, but he does not tell Marianne the reason. This plot suggests that there are some problems in their love and they will break up in the end.

1. For Willoughby

Facing Willoughby's departure, Marianne is overwhelmed by enormous grief. She cannot accept the terrible fact and hopes to come across Willoughby again in the future. So she played many favorite songs that she had been used to play to Willoughby. She always has illusions of Willoughby and believes they can have a reunion.

Unfortunately, when this heartless man writes to Marianne and tells her he will tie the knot with Miss Gray, the girl's expectations turn to desperation. But this innocent girl firmly believed that her Willoughby has secret sorrows. She always makes excuses for him and does not want to face the cruel reality. Although Elinor persuades her sister with the sane steady conviction and affectionate over and over again, Marianne is too impulsive to listen. Sometimes she could believe that Willoughby to be as unlucky and as innocent as herself. As we can see since Marianne trusted Willoughby too much so she cannot find out the truth and keep away from false appearance. Previously she dares to pursue everything she likes and someone she loves, but Marianne depends on Willoughby too excessively to see clearly the direction of love. Although he will engage to another girl, she still insists that Willoughby can change his decisions and marry her one day.

2. For Colonel Brandon

At this point, Colonel Brandon also hears about this sad news. Then he thinks again and decides to tell Elinor the truth. Willoughby is a playboy and he cheats on Miss Eliza, the stepdaughter of Colonel Brandon. When Marianne hears about the news, she just sheds tears and says nothing. At the same time, she is no longer avoids meeting Colonel Brandon but sympathizes his unfortunate experience and respects his selflessness. In a sense, Marianne is getting progress. She begins to find the advantages of Colonel Brandon and talks to him voluntarily. Gradually, she sees through Willoughby and feels very sorry to Colonel Brandon. Then, she no longer overlooks the kindness of this gentleman and tries her best to make friends with him.

\section{Marianne’s Views on Marriage And Reasons For Her Shift—From Sensibility to SenSE}

The United Kingdom is a rational country so that many people think sensibility should be controlled by sense. Jane Austen's heroine Elinor is also calm and rational when she encountered something. Although she is scarcely nineteen years old, she understands how to balance sense and emotion.

But another heroine Marianne is a counter example, her personalities are romantic, impulsive and enthusiastic. These personalities determine that her views of marriage will be full of sensibility and romanticism.

\section{A. Sensibility}

1. Pay more attention to handsome appearance

Marianne is a beautiful and lively girl, she has a pair of big and brown eyes, golden yellow hairs and red lip. She seems to have exhaustless enthusiasm and always sticks to herself (Austen, 1994, p. 39). The author Jane Austen describes her appearance in detail. Thus we can know that Marianne is a pretty beautiful girl and she is full of temperament and calm. In the meantime, the pursuit of fantasy is what Marianne wants. She likes to make a daydream; she loves to pursue nice and beautiful things; she hopes to meet a handsome Prince Charming.

One day, Marianne sprains her ankle in the process of climbing mountain, but fortunately, a noble and elegant man Willoughby saves her. All these personalities meet Marianne's requirements of her Mr. Right. But results do not match what Marianne has asked for. Willoughby thinks only of his own amusement, without any design of returning Marianne's affection. Soon after, he leaves her without any explanation.

2. Pay more attention to external hospitality

These are what Willoughby tells Elinor. He apologizes to her for all things he does to Marianne. At that time, hedonism is the only object that Willoughby wants to pursue, so he tries his best to win the attention of Marianne. If he succeeds to get her, he will have the amazing ability to appeal to other beautiful girls. But Marianne does not know what he really thinks. She always indulges in her romantic dream and does not want to wake up. When she cannot go outside because of foot injury, Willoughby visits her every day and talks many interesting stories with her. When she gets recovery, Willoughby presents a white horse to her in celebration of the recovery. His external hospitality makes Marianne love him rapidly. She deems that Willoughby will treat her well forever so she gives him her pure and whole heart. He is just for the vanity and hurts a kind girl's heart deeply.

3. Pay more attention to impractical illusion

Marianne's impractical illusion is her biggest weakness. That's closely related to her romantic personalities and because of this. Since her impractical illusion so she has great expectation to ideal love. Soon after, Marianne is 
abandoned by this playboy Willoughby. Her world of fantasy and spiritual pillar are both collapsed. Although Marianne falls into a deep pain and does not care about controlling herself at all, she still believes that Willoughby loves her. On the one hand, she persists in indulging the passion of illusion. On the other hand, she is constantly in pain with, keeps on the brink of choices. She does not know what to do and is trapped in contradiction. Her views on marriage are lack of sensibility so that Marianne will experience many setbacks in love.

\section{B. Sense}

In order to grow up, everyone needs to go through a lot of emotional pains. Marianne can deeply understand this feeling. She begins to grow up in order to overcome the pain, to fight with many wrong views and to win a better self. She gradually understands sensibility should be restricted by sense and becomes brave and rational. The following are rational views on marriage.

1. The rational marriage base on sincere heart

As for Colonel Brandon, he never even thinks about leaving Marianne when she is in adversity. When he saw Marianne for the first time, he appreciates her talent very much and deeply falls in love with this lovely girl. When Marianne has a bad cold, he looks after her without regret. In chapter forty-two, while Marianne lay on the bed, he looked at her with anxieties. The only thing he wants is she can get recovery as soon as possible. His eyes are filled with solicitude and cannot wait to look after Marianne all the time. Elinor also realizes Colonel Brandon's ideas (Austen, 1994. P. 267).

It is obvious that Colonel Brandon is a single-minded man. Unlike playboy Willoughby, he treats Marianne with sincerity and honesty. His concern and love make Marianne feel very self-condemned and moving, so she decides to begin a new life and nods her head to marry him in the end.

We can understand that good morality is more important than handsome appearance because the beautiful appearance is temporary but the sincere heart is everlasting.

2. The rational marriage base on money

In Marianne's immature mind, happiness is more significant than money. She thinks Willoughby will treat her well for long time regardless of how much money he has. Although money that Willoughby has is only one thousand pounds annual, it is not enough for them to live a really happy life, Marianne does not care about that. But things do not go as her willing. Willoughby's money soon runs out for pursuing pleasure. Fearing not having much money to squander, he makes a decision to get together with another rich girl and gives up Marianne. Money is not everything, but we can do nothing without money. That is the basement for the happy marriage.

3. The rational marriage base on mature personality

In this novel, Elinor is more rational than Marianne. So her rational personalities determine the rational marriage. As a broad-minded girl, she loves Edward very much just like Marianne loves Willoughby, but she can control her emotion rationally. When Elinor confirms the fact that Edward will get married with another girl who is Lucy, she can suffer the pain by herself and do not disturb everyone, including Edward, Lucy, Marianne and her mother. And then she decides to love Edward silently. She even helps him to find a job when Edward has no enough money to get married. Finally, she wins the respect and love of Edward by kindness and forbearance. That is what her sister Marianne does not have. Marianne thinks it is too difficult for her to control sadness so she just wants to release miserable feelings. She has a serious illness later so everyone is concerned about her, including her dear mother, Elinor as well as Colonel Brandon. Marianne's sentimental personalities determine her marriage will be tougher than Elinor.

\section{Reasons for Her Shift from Sense to Sensibility}

Many things we learned in life come from failures we experienced. When Willoughby leaves, Marianne is brokenhearted and almost loses her lives. But she stands up again with the help of many people who love her. There are several reasons of Marianne's change, including Willoughby's betrayal, Elioner's exhortation, Colonel Brandon's care and Marianne's self-salvation.

1. Willoughby's betrayal

Willoughby's betrayal is a direct reason for Marianne's shift from sense to sensibility. He just wants to indulge himself in happiness and vanity and does not care about Marianne's feeling at all. Because of his betrayal, Marianne is very grieved. The fact is relentless, but the reality makes Marianne see through Willoughby's hypocritical face, and it also breaks up Marianne's romantic views on marriage. She has to control herself and change her previous views. In a sense, the lovelorn is also a beneficial thing for her.

2. Elinor's encouragement

The second reason is Elinor's encouragement. She knows Marianne's agony in her mind so she tries all her best to make her sister feel good and distract her attention. In fact, during Marianne's painful period, Elinor is also miserable. She had already known Edward had a fiancee but she can do nothing. The only thing Elinor can do is keeping on living. When Marianne hears about all these things, guilt and self-accusation are all appeared in her mind. She feels very sorry to her sister and draws strength from the example of Elinor. Later in this novel, this brave girl walks out of the lovelorn shadows.

3. Colonel Brandon's care

One of the most virtual reasons of Marianne's change is Colonel Brandon's care. Although he maybe not welcomed 
by Marianne at first, he also has some advantages, like kindness, enthusiasm and integrity. When Marianne has a bad cold and soon is in danger, Colonel Brandon volunteers to help Elinor and Marianne fetch their mother to come here and look after her daughter. His kindness wins the appreciation of Marianne. In return, she begins to open her mind to this gentleman and apologizes to him for previous mistakes. She eventually noticed who deserves to be respected and loved, who are worth entrusting. Not Willoughby, this man is Colonel Brandon.

4. Marianne's self-salvation

Marianne's self-salvation is also a significant element. Although extraneous factors are helpful, self-salvation is more beneficial. If Marianne does not want to forget Willoughby, no one can help her. Sometimes we just have to save ourselves like Marianne.

After a big illness, Marianne finds a lot of weaknesses and mistakes she has and begins to make a plan to overcome them actively. She thinks her former self is selfish, lofty and biased so she cannot love others and herself. When Marianne makes a recovery from a bad cold, she realizes how childish and unforgivable she is. This girl apologizes to her sister Elinor and says sincerely that she will control her temper and put herself in other's shoes. Gradually, Marianne is making progress day by day and her temper is getting better. Soon after, she receives Colonel Brandon's proposal and returns to sense and reality rather than goes on living in anguish and illusion. She learns that morality is more virtal than appearance, understands the happy marriage should base on material conditions, learns from her sister Elinor and knows sensibility should be combined with sense and never indulges her emotion casually.

\section{CONCLUSION}

Elinor and Marianne are two heroines in Jane Austen's famous novel, one is rational and another is sentimental. To be honest, Marianne makes a deeper impression than Elinor on every reader's heart. She likes pursuing for freedom and romance. She hates red tape and pursues romantic even impractical love. But Marianne Dashwood is destined to have an unusual fate. She is born to find mistakes of her own views and correct them by experiencing many setbacks. In the end, she marries Colonel Brandon and becomes more mature. She grows from a young girl who is easy to be emotional into an responsible wife and a conscientious mother. The change of Marianne's views on marriage from sense to sensibility also reflects the truth: facing with love and marriage, we should be rational and control our emotion appropriately.

\section{ACKNOWLEDGMENTS}

In the process of accomplishing this paper, no words can show my deep feeling of appreciation to Professor He Ali, my respected and intelligent mentor, whose patience and intelligence will encourage me during the period of writing my paper which topic is From Sensibility to Sense - An Analysis on the Shift of Marianne's Views on Marriage in Sense and Sensibility and through my life. Not only has she impressed me on how to write the paper, but also encouraged me to be interested in English literature. What is more, I also want to thank my respected teachers in my university. I acquired a lot of knowledge from their courses and speeches, which has broadened my horizon in the process of English learning. They taught me many methods about literature research. After finishing my paper, I wish to show my sincere appreciate to my dear parents, who help me overcome lots of setbacks and give me too many supports and encouragements in my studying and living.

\section{REFERENCES}

[1] Austen Jane. (1994). Sense and Sensibility. Oxford: Oxford University Press.

[2] [British] Austen Jane. Sense and Sensibility. trans. Su Dan. (2009). Shaanxi: Shaanxi Normal University Press.

[3] Fu Jie. (2009). The Contrast and Affinity in Sense and Sensibility. Jiangxi Vocational \& Technical College of Electricity, 141.

[4] Lin Yin. (2013). Jane Austen's Views on Marriage from Sense and Sensibility. Bohai University, 115.

[5] Liang Xiangyang. (2010). Appreciation of Works about Jane Austen. The North Literature, 7, 12.

[6] Qian Jin. (2012). An Analysis of Jane Austen's Realistic Views on Marriage from Sense and Sensibility. Xinyang Vocational and Technical College, 268.

[7] Sun Yaling. (2012). The Ways of Marianne from Romance to Secular in Sense and Sensibility. Mang Zhong Literature, 200,180-181.

[8] Yang Huan. (2013). New Exploration of Austen's Marriage Pattern and Marriage Views. Nanjing Normal University, 9-10.

[9] Zhang Zhijuan. (2012). Keep the Balance between Sense and Sensibility, Reap the Happiness for Elinor and Marianne. Henan Institute of Science and Technology, 253-255.

Yuchao Zhang was born in Taiyuan, Shanxi Province, China in 1995. Her major was English and she graduated from Modern College of Arts and Science Shanxi Normal University in 2017. She is now pursuing a master's degree in English translation at Shanxi Normal University, Linfen, Shanxi Province in China. 